J. Dairy Sci. 99:2353-2357

http://dx.doi.org/10.3168/jds.2015-10159

(C) American Dairy Science Association ${ }^{\circledR}, 2016$.

\title{
Short communication: Plasma progesterone concentration and ovarian dynamics of lactating Jersey cows treated with 1 or 2 intravaginal progesterone inserts
}

\author{
João G. N. Moraes, ${ }^{* 1}$ Paula R. B. Silva, ${ }^{*}$ Nathália Bortoletto, $†$ Alexandre L. A. Scanavez, $†$ \\ and Ricardo C. Chebel†t ${ }^{2}$ \\ *Department of Veterinary Population Medicine, University of Minnesota, Saint Paul 55108 \\ †Department of Large Animal Clinical Sciences, and \\ ‡Department of Animal Sciences, University of Florida, Gainesville 32608
}

\begin{abstract}
The objectives of the current experiment were to determine circulating progesterone concentrations and ovarian follicle development of lactating Jersey cows treated with 1 or 2 controlled internal drug release (CIDR) insert containing $1.38 \mathrm{~g}$ of progesterone during proestrus. Cows were enrolled in the experiment at 34 $\pm 3 \mathrm{~d}$ in milk and were paired by parity, body condition score, body weight, and milk yield. Estrous cycles were presynchronized with an injection of GnRH concurrent with a new CIDR insert (study $\mathrm{d}-7$ ) and 2 injections of $\mathrm{PGF}_{2 \alpha}$ given 5 and $6 \mathrm{~d}$ after the $\mathrm{GnRH}$ injection (study d -2 and -1 , respectively). Cows assigned to the 1 CIDR treatment $(\mathrm{n}=30)$ or 2 CIDR treatment $(\mathrm{n}=30)$ received 1 and 2 CIDR inserts, respectively, from study d 0 through 7 . Control cows $(n=10)$ did not receive further treatment. On study $\mathrm{d}-2$ and daily from study d 0 through 7 , ovaries were examined by transrectal ultrasound and blood samples were collected for determination of progesterone. On study d 7, CIDR inserts were removed after ultrasound exam and blood sample collection. Progesterone concentration from study d 0 through 7 was greatest for 2CIDR cows $(2.17 \pm 0.09$ $\mathrm{ng} / \mathrm{mL})$, followed by 1 CIDR cows $(1.37 \pm 0.10 \mathrm{ng} / \mathrm{mL})$ and control cows $(0.62 \pm 0.21 \mathrm{ng} / \mathrm{mL})$. The interaction between treatment and study day affected progesterone concentration from study d 0 through 7 . The average increase in progesterone concentration from study $\mathrm{d} 1$ through 7 was $0.80 \mathrm{ng} / \mathrm{mL}$ for 1 CIDR and $1.72 \mathrm{ng} /$ $\mathrm{mL}$ for $2 \mathrm{CIDR}$ cows compared with control cows. The percentage of cows that ovulated between study $\mathrm{d} 0$ and 7 was greatest for control cows $(80 \%)$, but it did not differ between 1CIDR (12\%) and 2CIDR (3.7\%)
\end{abstract}

Received July 22, 2015.

Accepted October 26, 2015.

${ }^{1}$ Current address: Department of Animal Sciences, University of Missouri, Columbia, MO, 65211.

${ }^{2}$ Corresponding author: rcchebel@ufl.edu cows. Growth of class III follicles $(10-17 \mathrm{~mm})$ identified on study d 0 was affected by treatment because 1CIDR cows had larger class III follicles than 2CIDR cows on study d 5, 6 and 7. A larger proportion of control cows developed a new follicular wave between study $\mathrm{d} 0$ and $7($ control $=60.0 \%, 1 \mathrm{CIDR}=12.0 \%, 2 \mathrm{CIDR}=7.4 \%)$. Treatment of lactating Jersey cows with 1 and 2 CIDR inserts resulted in a 1 and 2 fold increase, respectively, in circulating progesterone concentration. Growth class III follicles from cows treated with 2 CIDR inserts was reduced compared with untreated cows and cows treated with 1 CIDR insert.

Key words: lactating Jersey cow, intravaginal progesterone insert, plasma concentration, follicle development

\section{Short Communication}

A shift in the breed composition of the US dairy herd, with increasing numbers of Jersey animals (NAHMS, 2007), may be attributed to increased market interest in milk solids rather than fluid milk. Although several studies have evaluated different reproductive strategies for lactating Jersey cows, the effects of controlled internal drug release (CIDR) insert treatment containing $1.38 \mathrm{~g}$ of progesterone on circulating concentrations of progesterone and follicular development have not been reported in lactating Jersey cows. Treatment of Holstein cows with 1 new CIDR insert results in a 0.78-ng/ $\mathrm{mL}$ increase in circulating progesterone concentration (Cerri et al., 2009), which is insufficient to improve fertility of cows not bearing a functional corpus luteum (CL; Rivera et al., 2011; Denicol et al., 2012). Treatment of lactating cows with 1 CIDR insert may not improve embryo viability because the small increase in progesterone concentration resulting from CIDR treatment may result in increased LH pulsatility during follicle development, which is believed to result in faster follicle development and compromised oocyte quality (Cerri et al., 2009). 


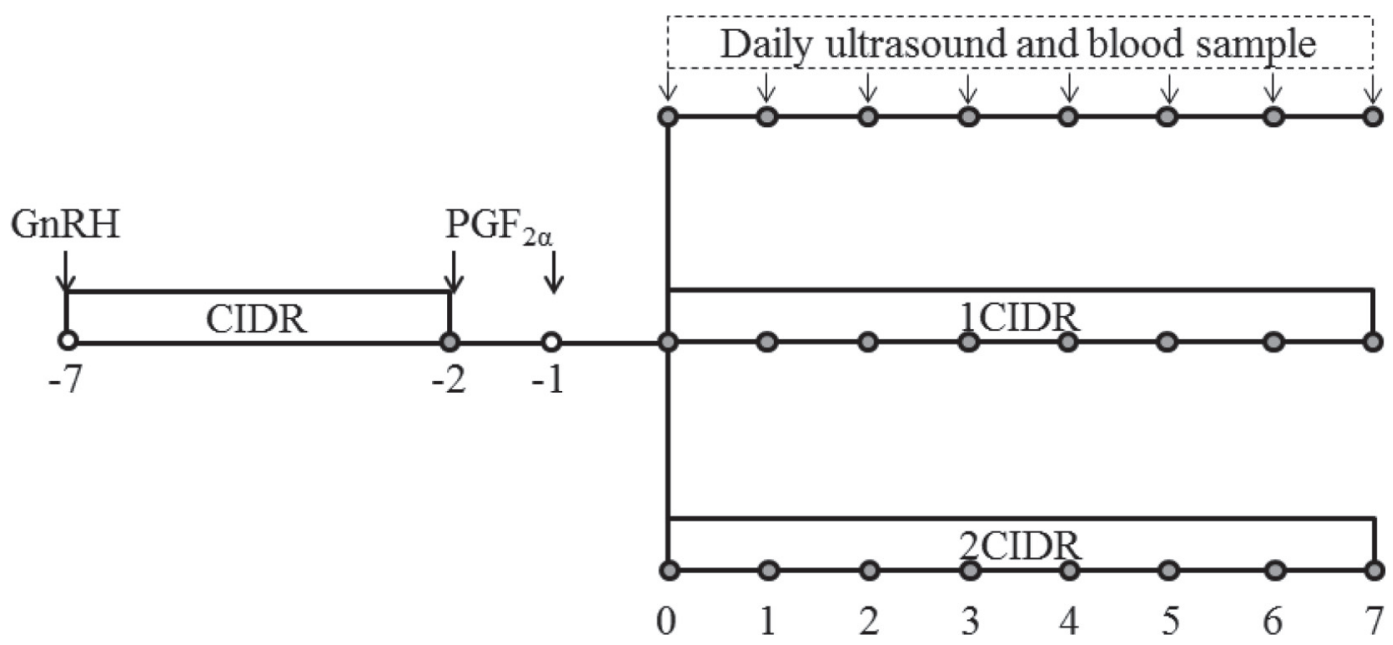

Figure 1. Diagram of activities. Estrous cycles were presynchronized with an injection of $100 \mu \mathrm{g}$ of GnRH (gonadorelin diacetate tetrahydrate; $2 \mathrm{~mL}$ of Cystorelin; Merial Ltd., Iselin, NJ) concurrent with a new controlled internal drug release (CIDR) insert (Eazi-Breed CIDR Cattle Insert; Zoetis Animal Health, Madison, NJ) on study d -7 , and 2 injections of $25 \mathrm{mg}$ of $\mathrm{PGF}_{2 \alpha}$ (dinoprost tromethamine, $5 \mathrm{~mL}$ of Lutalyse sterile solution; Zoetis Animal Health) given on study d -2 and -1 . Cows assigned to the 1 CIDR treatment $(\mathrm{n}=30)$ received 1 new CIDR insert from study d 0 through 7 , cows assigned to the 2CIDR treatment $(\mathrm{n}=30)$ received 2 new CIDR inserts from study d 0 through 7 , and control cows $(\mathrm{n}=10)$ did not receive further treatments. Grey circles represent ultrasound (5 MHz, Ibex Lite, E. I. Medical Imaging, Loveland, CO) exam of ovaries and blood sample collection for determination of progesterone concentration.

The hypothesis of the current experiment was that treatment of Jersey cows with 1 CIDR insert would result in an increase in progesterone concentration of 0.6 to $0.8 \mathrm{ng} / \mathrm{mL}$, whereas treatment of Jersey cows with 2 CIDR inserts would result in an increase in progesterone concentration of approximately 1.6 to $2.0 \mathrm{ng} /$ $\mathrm{mL}$. This hypothesis was based on previously published work with Holstein cows treated with 1 CIDR insert (Cerri et al., 2009). Another hypothesis of the current experiment was that growth of follicles of Jersey cows treated with 1 or 2 CIDR inserts would be reduced compared with untreated Jersey cows. Therefore, the objectives of the current experiment were to determine circulating progesterone concentrations and follicular growth of lactating Jersey cows treated with 1 or 2 CIDR insert containing $1.38 \mathrm{~g}$ of progesterone during proestrus.

The experiment was conducted in a cross-ventilated freestall commercial dairy farm located in south-central Minnesota during the month of October 2010. Cows at $34 \pm 3$ DIM were balanced for parity, BCS, BW, and milk yield in the first month of lactation and allocated randomly to 1 of 3 treatments. For every cow allocated to the control $(\mathrm{n}=10), 3$ cows were allocated to a treatment receiving 1 insert $(\mathbf{1 C I D R} ; \mathrm{n}=30)$ and 3 cows were allocated to a treatment receiving 2 inserts (2CIDR; $\mathrm{n}=30)$. Body condition was scored in a scale from 1 (thin) to 5 (obese) according to (Ferguson et al., 1994) and BW was determined using heart girth circumference weight tapes for Jersey cows (The Co- burn Company Inc., Whitewater, WI). Estrous cycles were presynchronized with an injection of $100 \mu \mathrm{g}$ of $\mathrm{GnRH}$ (gonadorelin diacetate tetrahydrate; $2 \mathrm{~mL}$ of Cystorelin; Merial Ltd., Iselin, NJ) concurrent with a new CIDR insert (Eazi-Breed CIDR Cattle Insert; Zoetis Animal Health, Madison, NJ) on study d -7 , and 2 injections of $25 \mathrm{mg}$ of $\mathrm{PGF}_{2 \alpha}$ (dinoprost tromethamine, $5 \mathrm{~mL}$ of Lutalyse sterile solution; Zoetis Animal Health, Madison, NJ) given on study $\mathrm{d}-2$ and -1 . Cows assigned to the 1CIDR treatment received 1 new CIDR insert from study d 0 through 7 , cows assigned to the 2CIDR treatment received 2 new CIDR inserts from study d 0 through 7 , and control cows did not receive further treatments (Figure 1).

Ovaries were examined by transrectal ultrasound ( 5 $\mathrm{MHz}$, Ibex Lite, E. I. Medical Imaging, Loveland, CO) on study $\mathrm{d}-2$ for the presence of a dominant follicle $(\geq 10 \mathrm{~mm})$ and corpora lutea, and daily from study $\mathrm{d}$ 0 through 7 for measurement and mapping of ovarian structures (follicles $\geq 3 \mathrm{~mm}$ and corpora lutea). On study d 0, ovarian follicles were categorized according to their diameter as class I $(\leq 4 \mathrm{~mm})$, class II $(5-9 \mathrm{~mm})$, class III (10-17 mm), and class IV ( $\geq 18 \mathrm{~mm})$. Ovulation was inferred when a large follicle $(>10 \mathrm{~mm})$ was observed in 1 ultrasound exam and was not observed in 2 consecutive ultrasound exams thereafter. Interval from study $\mathrm{d}-2$ to ovulation was inferred as being the $12 \mathrm{~h}$ after the last ultrasound exam in which the follicle was observed. A new follicular wave was characterized by the identification and continued growth (observed 
over $>2$ consecutive ultrasound exams) of a new follicle $\geq 3 \mathrm{~mm}$. Corpus luteum (CL) volume was calculated by the following formula (Kenyon et al., 2012):

$$
\begin{aligned}
& \sum\left(\left\{4 / 3 \times \pi \times\left[\left(\mathrm{d}_{\mathrm{a}} / 2+\mathrm{d}_{\mathrm{b}} / 2\right) / 2\right]^{3}\right\}\right. \\
- & \left.\left\{4 / 3 \times \pi \times\left[\left(\mathrm{c}_{\mathrm{a}} / 2+\mathrm{c}_{\mathrm{b}} / 2\right) / 2\right]^{3}\right\}\right),
\end{aligned}
$$

where $d_{a, b}$ and $c_{a, b}$ are orthogonal luteal and cavity dimensions, respectively, for the nth CL.

Blood samples were collected from the coccygeal vein or artery using evacuated tubes containing K2 EDTA (Becton Dickinson Vacutainer Systems, Franklin Lakes, NJ) on study $d-2$ and daily from study d 0 through 7. Cows that on study $\mathrm{d}-2$ had a CL or progesterone concentration $\geq 1 \mathrm{ng} / \mathrm{mL}$ were considered to be cyclic. Blood samples were placed on ice until centrifugation at $1,200 \times g$ for $15 \mathrm{~min}$ at $4^{\circ} \mathrm{C}$. Plasma was separated and frozen at $-32^{\circ} \mathrm{C}$ for hormone analysis. Concentrations of progesterone were determined in all samples using a solid-phase radioimmunoassay kit (Coat-a-Count, Siemens Medical Solutions Diagnostics, Los Angeles, $\mathrm{CA})$. Intra- and interassay coefficients of variation were 10.1 and $5.1 \%$, respectively. On study d 7, CIDR inserts were removed after blood sample collection and ultrasound exam of ovaries. Cows were milked thrice daily and received recombinant bST (500 mg of Posilac; Elanco, Greenfield, IN) treatment every $10 \mathrm{~d}$ starting at $56 \pm 3 \mathrm{~d}$ postpartum.

Only data from cows that had complete luteolysis from study d -2 to 0 were used. All data were analyzed using SAS version 9.3 (SAS/STAT, SAS Institute Inc., Cary, NC). Binomial data were analyzed by Chi-square and Fisher's exact tests using the FREQ procedure. Continuous data measured at enrollment (e.g., BCS, BW, lactation number, milk yield) and on study d -2 (e.g., progesterone concentration) were analyzed by ANOVA using the GLM procedure with treatment as the explanatory variable. Continuous data measured over time (study d 0 through 7 ) were analyzed by ANOVA for repeated measures using the MIXED procedure. To eliminate the confounding effect of endogenous progesterone on circulating progesterone concentration from study d 0 through 7 , progesterone data of cows that ovulated during CIDR treatment was not used in the statistical analysis after ovulation was detected. Furthermore, follicle growth data were analyzed only for cows that did not ovulate between study d 0 and 7. Treatment, study day, and the interaction between treatment and study day were forced in every model as explanatory variables. In the analysis of follicle growth, cyclic status was included to the model and when $P$ $\geq 0.15$ it was removed from the model. In the current experiment, statistical significance was defined as $P \leq$ 0.05 and statistical tendencies as $0.05<P<0.15$.

No differences were detected among treatments regarding lactation number (control $=2.60 \pm 0.29$, $1 \mathrm{CIDR}=2.40 \pm 0.19,2 \mathrm{CIDR}=2.52 \pm 0.18 ; P=$ 0.82 ), BCS (control $=3.18 \pm 0.13,1 \mathrm{CIDR}=3.11 \pm$ $0.08,2 \mathrm{CIDR}=3.16 \pm 0.08 ; P=0.88)$, BW (control $=$ $426.1 \pm 13.1,1 \mathrm{CIDR}=421.2 \pm 8.3,2 \mathrm{CIDR}=418.5$ $\pm 7.9 \mathrm{~kg} ; P=0.88)$, and average milk yield during the first 60 DIM (control $=28.4 \pm 1.6,1 \mathrm{CIDR}=29.9 \pm$ $1.0,2 \mathrm{CIDR}=28.6 \pm 1.0 \mathrm{~kg} ; P=0.56)$. Data from 8 cows (five 1CIDR and three 2CIDR cows) were removed from the analysis because they had a CL present in the ovary on $\mathrm{d}-2$ that did not undergo complete luteolysis between study $\mathrm{d}-2$ and 0 .

On study d -2 , progesterone concentration (control $=3.36 \pm 0.94,1 \mathrm{CIDR}=3.80 \pm 0.60,2 \mathrm{CIDR}=3.13$ $\pm 0.57 \mathrm{ng} / \mathrm{mL} ; P=0.72$ ) and percentage of cows with progesterone concentration $\geq 1 \mathrm{ng} / \mathrm{mL}$ (control $=70.0$, $1 \mathrm{CIDR}=70.4,2 \mathrm{CIDR}=84.0 \% ; P=0.49) \mathrm{did}$ not differ among treatments. From study d 0 through 7 , treatment did not $(P=0.82)$ affect the volume of the $\mathrm{CL}$ that had been diagnosed on study $\mathrm{d}-2$. The interaction between treatment and study day, however, affected $(P=0.02)$ the volume of the CL that had been diagnosed on study $\mathrm{d}-2$ because on study d 0 CL volume of control cows was greater than CL volume of 1CIDR $(P=0.01)$ and 2CIDR $(P=0.02)$ cows and on study d $1 \mathrm{CL}$ volume of control cows was $(P=0.04)$ greater than CL volume of 2CIDR cows (Figure 2). Thereafter, volume of the CL diagnosed on study d -2 did not $(P>0.15)$ differ among treatments. Progesterone concentration from study d 0 through 7 was $(P<0.01)$ greatest for 2 CIDR cows $(2.17 \pm 0.09 \mathrm{ng} /$ $\mathrm{mL})$, followed by 1CIDR cows $(1.37 \pm 0.10 \mathrm{ng} / \mathrm{mL})$ and control cows $(0.62 \pm 0.21 \mathrm{ng} / \mathrm{mL}$; Figure 3$)$. The interaction between treatment and study day affected $(P<0.01)$ progesterone concentration from study $\mathrm{d}$ 0 through 7 because on study d 0 there were no $(P>$ $0.15)$ differences in progesterone concentration among treatments (control $=0.96 \pm 0.31,1 \mathrm{CIDR}=1.31 \pm$ $0.19,2 \mathrm{CIDR}=1.31 \pm 0.18 \mathrm{ng} / \mathrm{mL})$. Furthermore, on study d 5 (control $=0.55 \pm 0.30,1 \mathrm{CIDR}=1.16 \pm$ $0.12 \mathrm{ng} / \mathrm{mL} ; P=0.06)$ and 6 (control $=0.50 \pm 0.40$, $1 \mathrm{CIDR}=1.14 \pm 0.14 \mathrm{ng} / \mathrm{mL} ; P=0.13)$ progesterone concentration of control cows tended to be lower than 1 CIDR cows. On study d 7 , progesterone concentration of 1 CIDR cows $(1.49 \pm 0.20 \mathrm{ng} / \mathrm{mL})$ did not differ from control $(0.68 \pm 0.59 \mathrm{ng} / \mathrm{mL} ; P=0.19)$ and 2 CIDR $(1.89 \pm 0.19 \mathrm{ng} / \mathrm{mL} ; P=0.15)$ cows. The average increase in progesterone concentration from study d 1 through 7 was of $0.80 \mathrm{ng} / \mathrm{mL}$ for 1CIDR and $1.72 \mathrm{ng} /$ $\mathrm{mL}$ for 2 CIDR cows compared with control cows. 


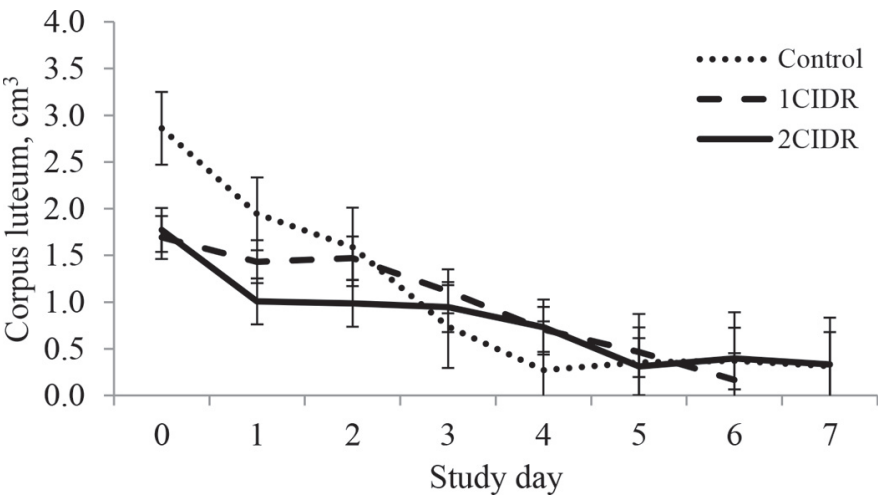

Figure 2. Volume of the corpus luteum present in the ovaries on study $\mathrm{d}-2$. Treatments were control $(\mathrm{n}=8)$ and $1(1 \mathrm{CIDR} ; \mathrm{n}=25)$ or 2 controlled internal drug release (2CIDR; $\mathrm{n}=23$ ) inserts. Vertical lines represent the SEM. Effects: treatment, $P=0.82$; study day, $P$ $<0.01$; treatment by study day interaction, $P=0.02$. Corpus luteum volume on study d 0 was greater for control cows than 1CIDR $(P=$ $0.01)$ and 2CIDR $(P=0.02)$ cows. Corpus luteum volume on study d 1 was $(P=0.04)$ greater for control cows than 2CIDR cows.

The percentage of cows that ovulated between study d 0 and 7 was $(P<0.01)$ greatest for control cows (80\%), but no difference between 1CIDR (12\%) and 2CIDR $(3.7 \%)$ cows was detected. No differences $(P=$ $0.50)$ were observed among treatments regarding the interval from study $\mathrm{d}-2$ to ovulation (control $=128.8$ $\pm 9.1,1 \mathrm{CIDR}=152.8 \pm 16.9,2 \mathrm{CIDR}=119.2 \pm 26.4$ h). On study d 0 , the diameter of the follicles that ovulated between study d 0 and 7 was $(P=0.02)$ and tended $(P=0.08)$ to be smaller for 1CIDR cows $(11.7$ $\pm 2.1 \mathrm{~mm})$ compared with control $(18.6 \pm 1.3 \mathrm{~mm})$ and 2CIDR $(20.0 \pm 3.6 \mathrm{~mm})$ cows.

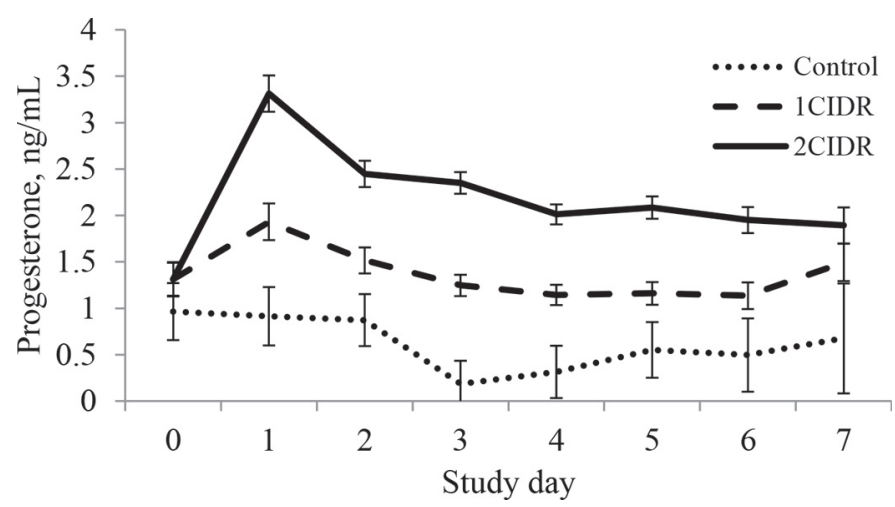

Figure 3. Progesterone concentration from study d 0 through 7 . Treatments were control $(\mathrm{n}=10)$ and $1(1 \mathrm{CIDR} ; \mathrm{n}=25)$ or 2 controlled internal drug release $(2 \mathrm{CIDR} ; \mathrm{n}=27)$ inserts. Vertical lines represent the SEM. Effects: treatment, $P<0.01$; study day, $P<0.01$; treatment by study day interaction, $P<0.01$. Progesterone concentration was not different between treatments on study d $0(P \geq 0.33)$ Progesterone concentration tended to be greater for 1CIDR cows on study d $5(P=0.06)$ and $6(P=0.13)$ than control cows. On study d 7 , progesterone concentration of 1 CIDR cows did not differ from that of control $(P=0.19)$ and 2CIDR $(P=0.15)$ cows
Among cows that did not ovulate from study d 0 through 7, 1 cow from the 2CIDR treatment had class I follicles, 24 cows had class II follicles (2 control, nine 1CIDR, and thirteen 2CIDR cows), 35 cows had class III follicles (2 control, sixteen 1CIDR, and seventeen 2 CIDR cows), and 18 cows had class IV follicles (six 1 CIDR and twelve 2CIDR cows) on study d 0 . Growth of follicles class II was not affected by treatment $(P=$ 0.81 ) and by the interaction between treatment and study day $(P=0.58$; Figure $4 \mathrm{~A})$. On the other hand, a tendency $(P=0.13)$ for treatment to affect diameter of class III follicles was noted from study d 0 through 7 (Figure 4B). Class III follicles tended $(P=0.08)$ to be larger for 1CIDR than 2CIDR cows on study d 4, and they were larger for 1CIDR than 2CIDR cows on study d 5, 6, and $7(P \leq 0.01)$. Class III follicles tended to be larger for control than 2CIDR cows on study d 5 ( $P$ $=0.11)$ and $6(P=0.09)$. Growth of class IV follicles from study d 0 through 7 was not $(P=0.73)$ different between 1CIDR and 2CIDR cows (Figure 4C). A larger $(P<0.01)$ proportion of control cows developed a new follicular wave between study d 0 and 7 (control $=60.0 \%, 1 \mathrm{CIDR}=12.0 \%, 2 \mathrm{CIDR}=7.4 \%)$. No differences $(P=0.25)$ in the interval from study $\mathrm{d}-2$ to the detection of the new follicular wave were observed $($ control $=122.7 \pm 12.9,1 \mathrm{CIDR}=89.3 \pm 18.0,2 \mathrm{CIDR}$ $=76.0 \pm 24.1 \mathrm{~h})$.

The current experiment evaluated the concentrations of progesterone, follicle growth, and likelihood of ovulation of lactating Jersey cows treated with 1 or 2 new CIDR inserts at the start of the proestrus. Similar to what had been described for lactating Holstein cows (Cerri et al., 2009; Denicol et al., 2012), treatment of lactating Jersey cows with 1 CIDR insert produced an increase in progesterone concentration of $0.8 \mathrm{ng} / \mathrm{mL}$ compared with control cows. Conversely, treatment of lactating Jersey cows with 2 CIDR inserts resulted in an increase in progesterone concentration of $1.7 \mathrm{ng} / \mathrm{mL}$ compared with control cows. As reported previously for lactating Holstein cows (Cerri et al., 2009), progesterone concentrations were greatest among 1CIDR and 2CIDR cows within $24 \mathrm{~h}$ of treatment with CIDR insert, and a sharp decrease in progesterone concentration was observed thereafter, reaching a nadir 3 to $4 \mathrm{~d}$ after the treatment. The increase in progesterone concentration in plasma following treatment with a CIDR insert is determined by the surface area of the insert that is in contact with the vagina (Rathbone et al., 2002), by the metabolism of progesterone (Sangsritavong et al., 2002), and, to a lesser extent, by the characteristics of the insert (Rathbone et al., 2002). Although the current experiment did not allow for a comparison of Jersey and Holstein cows, the findings of the current experiment lead to the speculation that small differences exist, if 
A.

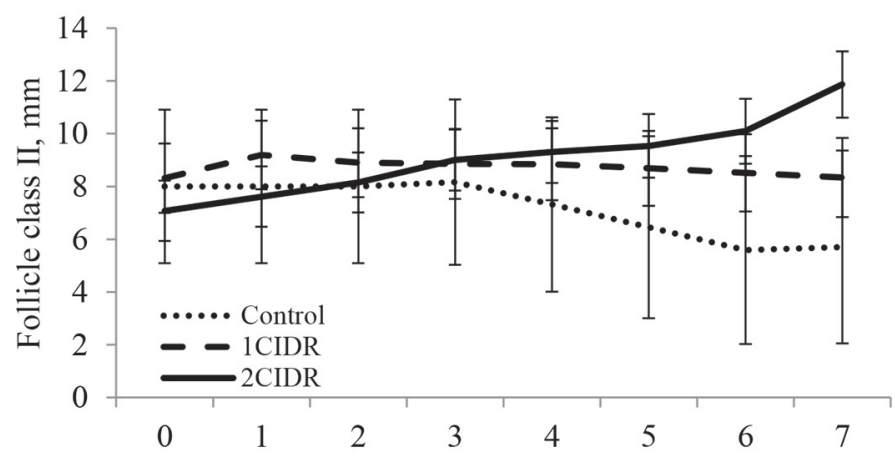

B.

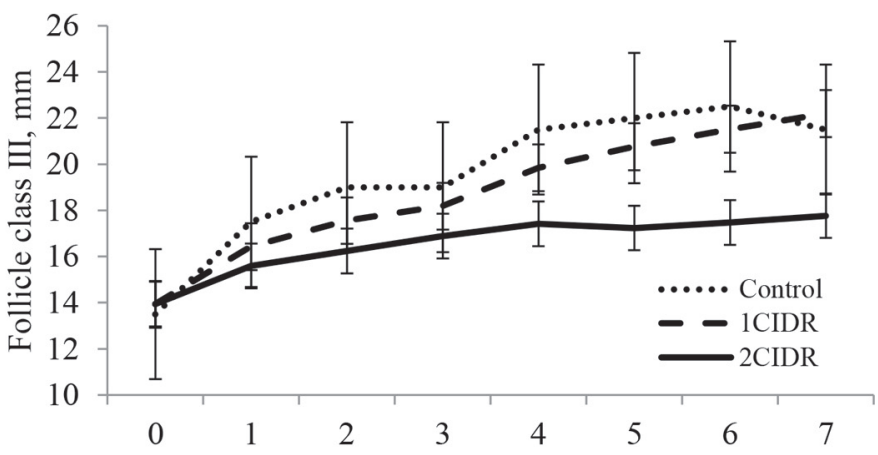

C.

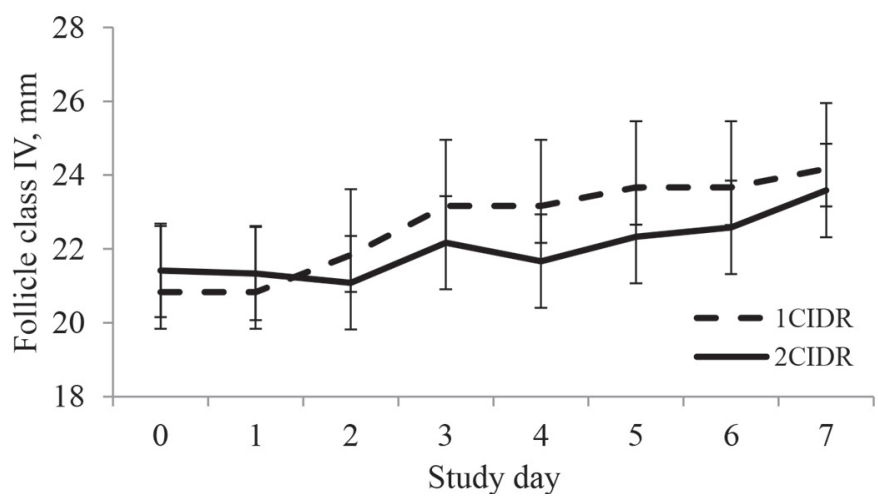

Figure 4. (A) Class II follicle growth from study d 0 through 7 . Treatments were control $(\mathrm{n}=2)$ and $1(1 \mathrm{CIDR} ; \mathrm{n}=9)$ or 2 controlled internal drug release (2CIDR; $\mathrm{n}=13$ ) inserts. Vertical lines represent the SEM. Effects: treatment, $P=0.81$; study day, $P=0.93$; treatment by study day interaction, $P=0.58$. (B) Class III follicle growth from study d 0 through 7 . Treatments were control $(\mathrm{n}=2), 1$ CIDR $(\mathrm{n}=$ 16), and 2CIDR $(\mathrm{n}=17)$. Vertical lines represent the SEM. Effects: treatment, $P=0.13$; study day, $P<0.01$; treatment by study day interaction, $P=0.54$. Class III follicles tended $(P=0.08)$ to be larger for 1CIDR than 2CIDR cows on study d 4 , and they were larger for 1 CIDR than 2 CIDR cows on study d 5,6 , and $7(P \leq 0.01)$. Class III follicles tended to be larger for control than 2CIDR cows on study d 5 $(P=0.11)$ and $6(P=0.09)$. (C) Class IV follicle growth from study d 0 through 7 . Treatments were 1CIDR $(\mathrm{n}=6)$ and 2 CIDR $(\mathrm{n}=12)$. Vertical lines represent the SEM. Effects: treatment, $P=0.73$; study day, $P=0.17$; treatment by study day interaction, $P=0.97$. any, between Holstein and Jersey cows regarding their responses to treatment with intravaginal progesterone inserts.

The observed effects of reduced progesterone concentration on ovarian follicles of lactating Jersey cows, namely reduced growth of class III follicles and likelihood of ovulation, also have been reported in Holstein cows (Cerri et al., 2009; Denicol et al., 2012). These are important findings because, in Holstein cows, growth of ovulatory follicles under progesterone concentrations $<2 \mathrm{ng} / \mathrm{mL}$ has been reported to reduce embryo quality (Rivera et al., 2011) and pregnancy per AI (Denicol et al., 2012). Therefore, one may speculate that treatment of lactating Jersey cows that do not have an active CL (progesterone concentration $<1 \mathrm{ng} / \mathrm{mL}$ ) at the start of an ovulation synchronization protocol with 2 CIDR inserts may significantly improve their reproductive performance.

\section{ACKNOWLEDGMENTS}

The authors thank the owner and staff of the collaborating dairy for the use of their cows and facilities. The authors extend their appreciation to the College of Veterinary Medicine of the University of Minnesota for partial funding through the Grant-in-Aid Program.

\section{REFERENCES}

Cerri, R. L. A., H. M. Rutigliano, R. G. S. Bruno, and J. E. P. Santos. 2009. Progesterone concentration, follicular development and induction of cyclicity in dairy cows receiving intravaginal progesterone inserts. Anim. Reprod. Sci. 110:56-70.

Denicol, A. C., G. Lopes Jr., L. G. Mendonça, F. A. Rivera, F. Guagnini, R. V. Perez, J. R. Lima, R. G. Bruno, J. E. Santos, and R. C. Chebel. 2012. Low progesterone concentration during the development of the first follicular wave reduces pregnancy per insemination of lactating dairy cows. J. Dairy Sci. 95:1794-1806.

Ferguson, J. D., D. T. Galligan, and N. Thomsen. 1994. Principal descriptors of body condition score in HO cows. J. Dairy Sci. 77:2695-2703.

Kenyon, A. G., G. Jr. Lopes, L. G. D. Mendonça, J. R. Lima, R. G. Bruno, A. C. Denicol, and R. C. Chebel. 2012. Ovarian responses and embryo survival in recipient lactating Holstein cows treated with equine chorionic gonadotropin. Theriogenology 77:400-411.

NAHMS. 2007. Dairy 2007 Part I: Reference of dairy cattle health and management practices in the United States, 2007. National Animal Health Monitoring System, USDA, Washington, DC.

Rathbone, M. J., C. R. Bunt, C. R. Ogle, S. Burggraaf, K. L. Macmillan, C. R. Burke, and K. L. Pickering. 2002. Reengineering of a commercially available bovine intravaginal insert (CIDR insert) containing progesterone. J. Control Release 85:105-115.

Rivera, F. A., L. G. D. Mendonça, G. Lopes Jr., J. E. Santos, R. V. Perez, M. Amstalden, A. Correa-Calderón, and R. C. Chebel. 2011. Reduced progesterone concentration during growth of the first follicular wave affects embryo quality but has no effect on embryo survival post transfer in lactating dairy cows. Reproduction 141:333-342.

Sangsritavong, S., D. K. Combs, R. Sartori, L. E. Armentano, and M. C. Wiltbank. 2002. High feed intake increases liver blood flow and metabolism of progesterone and estradiol-17 in dairy cattle. J. Dairy Sci. 85:2831-2842. 